Potravinarstvo Slovak Journal of Food Sciences

vol. 15, 2021, p. 95-100

https://doi.org/10.5219/1505

Received: 9 November 2020. Accepted: 22 December 2020.

Available online: 28 February 2021 at www.potravinarstvo.com

(C) 2021 Potravinarstvo Slovak Journal of Food Sciences, License: CC BY 4.0

ISSN 1337-0960 (online)

\title{
MICROBIOLOGICAL, CHEMICAL AND ORGANOLEPTIC EVALUATION OF FRESH FISH AND ITS PRODUCTS IRRADIATED BY GAMMA RAYS
}

\author{
Amal Nasser Al-Kuraieef
}

\begin{abstract}
The present study evaluated the microbiological, chemical, and organoleptic aspects of irradiated fresh fish and its products to extend their shelf life. Fresh fish and its products were irradiated at three doses $(1.5,3.0$, and $4.5 \mathrm{kGy})$ used for preservation to study the effects of irradiation on their microbiological properties, fatty acid composition, and organoleptic properties. Irradiated fresh bolti fish, smoked herring, and smoked mackerel were evaluated microbiologically, chemically, and organoleptically. Radiation treatment not only reduced the counts of aerobic bacteria, fecal streptococci, molds, and yeasts but also destroyed all the Staphylococcus aureus cells, improving the hygienic quality of the fresh and smoked fish samples. Irradiation increased the peroxide, acid, and thiobarbituric acid values, but they remained within acceptable levels. No new fatty acids or other artifacts due to irradiation were observed. Irradiation of $4.5 \mathrm{kGy}$ greatly reduced the organoleptic quality scores of fresh bolti fish, indicating that the optimum radiation dose for this fish was $3.0 \mathrm{kGy}$. Smoked herring and mackerel could be irradiated with up to $4.5 \mathrm{kGy}$ without adverse effects on their organoleptic properties.
\end{abstract}

Keywords: microbiological; chemical; organoleptic; fish; irradiated

\section{INTRODUCTION}

Currently, irradiated food (up to $10 \mathrm{kGy}$ ) has become acceptable and is commercially available in many countries worldwide (Lacroix and Ouattara, 2000; Demartini et al., 2019).

Radiation sterilization, which is analogous to the processing techniques used for other meats (beef, poultry, and seafood), is also a new and promising method applicable to the processing of precooked meats (enzyme inactivation). Radiation sterilized foods can be stored for a long time (years) without refrigeration (Duliu, Ferdes, and Ferdes, 2004; Sedeh et al., 2007; Fallah et al., 2008; Kakatkar et al., 2017). Many studies of potential techniques for the commercial radiation sterilization of seafood have been carried out because radiation extends the shelf life of the product and improves the hygienic quality of the seafood (Chouliara et al., 2004; Brennan, 2005; Özkan et al., 2007).

The lipids in the fish muscle are different from those of other animal tissues due to their high contents of polyunsaturated fatty acids (Al-Kahtani et al., 1996; Javanmard et al., 2006; Özden and Erkan, 2010).

The high polyunsaturated fat content can be considered the main reason for the oxidative rancidity of fish, which adversely affects its flavor. Irradiation has been reported to increase 2-thiobarbituric acid-reactive substances (TBARS) in aerobically packaged raw poultry meat (Du et al., 2000; Turgis et al., 2008).
Irradiation has shown considerable promise in the microbial decontamination of fresh fish and fish products, extending their shelf lives and improving their hygienic quality (Farkas, 2006; Mbarki et al., 2009). However, the acceptability of irradiated fish products is dependent on the chemical composition of the fish, particularly the lipids. Many investigators have found that irradiation in the presence of oxygen can accelerate lipid oxidation and induce oxidative rancidity; hence, lipid quality and fatty acid composition can be altered (Byun et al., 2008; Mbarki et al., 2009). The progressive use of gamma radiation in the field of fish and fish product preservation makes it important to evaluate radiation processes and their effects on the qualities of these products (Badr, 2012).

Bolti (Tilapia nilotica) is one of the most important and preferred freshwater fish. Smoked fish products have received more attention due to their pleasant taste. The most important types of smoked fish are herring and mackerel (WHO, 2000; Nickelson et al., 2001).

Fresh and smoked fish products can be contaminated with many pathogenic microorganisms that affect their shelf life (Moini et al., 2009; Rostamzad et al., 2010).

The main aim of the present study was to evaluate the effects of gamma irradiation on the microbiological, chemical, and organoleptic qualities of fish (fresh bolti fish as well as smoked herring and smoked mackerel). 


\section{Scientific hypothesis}

H1: Radiation is considered a safe method of preserving food from microbial deterioration and consequently prolonging its marketing period.

H2: Gamma irradiation we will be using for the fresh fish and smoked improving the hygienic quality and increasing its shelf life without adverse effects on its organoleptic properties.

\section{MATERIAL AND METHODOLOGY}

Three types of fish, fresh bolti (Tilapia nilotica), smoked herring, and smoked mackerel, were used in this experiment. Fresh bolti fish samples were obtained from the Dammam fish market in the eastern province of Saudi Arabia. This market is one of the main sources of fish in the kingdom, while smoked herring and smoked mackerel were obtained from the market in Riyadh, Saudi Arabia. The fish samples were wrapped with non-perforated plasticized polyvinyl chloride (PVC) film, which is a stretch film with high transparency, 12-micron thickness, self-clinging, and the following rates of permeability: $\mathrm{CO}_{2}>100 \mathrm{~cm}^{3} / \mathrm{m}^{2} / 24$ $\mathrm{hr} ; \mathrm{O}_{2} 1800 \mathrm{~cm}^{3} / \mathrm{m}^{2} / 24 \mathrm{hr}$; and water vapor $700 \mathrm{~g} / \mathrm{m}^{2} / 24 \mathrm{hr}$.

\section{Irradiation process}

Fish samples in bags were irradiated for 30 Minutes. The samples temperature was when irradiation at $2-3{ }^{\circ} \mathrm{C}$ $\pm 1{ }^{\circ} \mathrm{C}$ were exposed to $1.5,3.0$, and $4.5 \mathrm{kGy}$ from cobalt 60 in a Gammacell 220 at King Abdul Aziz City for Science and Technology (KACST) in Riyadh (Model Gammacell 220 from MDS; Nordion Initial Canada Activity source (Co-60) was 24.000). All fish samples were stored at $3^{\circ} \mathrm{C}$ $\pm 1{ }^{\circ} \mathrm{C}(90-92 \% \mathrm{RH})$.

\section{Microbiological tests}

The total aerobic bacterial counts were enumerated on agar (Merck, Darmstadt, Germany) plates as described by Maturin and Peeler (2001). The quantification of fecal streptococci was done through the MPN technique using the Dextrose Azide Broth (APHA, 1998), while Staphylococcus aureus was counted on Baird-Parker medium as described by Tallent et al. (2001). The total molds and yeasts were counted on malt extract agar plates (Tournas et al., 2001).

\section{Lipid extraction}

The parts of fish were homogenized and $5 \mathrm{~g}$ of the homogenized sample was mixed well with $10 \mathrm{~g}$ cleaned sea sand and $20 \mathrm{~g}$ anhydrous sodium sulfate, and then percolated for 6 hours with a hexane-acetone mixture $(2: 1)$ in a glass column with a Teflon stopcock. After evaporation of the solvent from the percolate $(600 \mathrm{~mL})$ under vacuum (all chemicals were from Fischer, USA), the fish lipids extracted were weighed (AOAC, 1990).

\section{Lipid quality attributes}

The peroxide value (as equivalents $/ \mathrm{kg}$ lipid) and the acid value were determined as described by AOAC (1990). The thiobarbituric acid value was determined according to performed as described by Lynch and Frei (1993).

\section{Fatty acid profiles}

The fatty acid composition was determined by a gas-liquid chromatography apparatus according to the method by AOAC (1990).

\section{Organoleptic tests}

The appearance, odor, texture, and taste of the fish samples were served to a taste panel of 10 members using a hedonic scale of 1 to 9 and the dishes were rated as 9 for excellent, 6 for good and below 4 as poor or unacceptable. (WHO, 2000).

\section{Statistical Analysis}

The obtained data are reported as the mean $\pm S D$ and were statistically analyzed using SPSS program version 22.0 (SPSS, 2018, SPSS Inc., Chicago, Illinois, USA). Significant differences were evaluated by Duncan's multiple range test (DMRT), with differences considered significant at $p<0.05$.

\section{RESULTS AND DISCUSSION}

The results of the microbiological tests are shown in Table 1. A comparison of the fresh bolti fish and smoked fish (herring and mackerel) indicated that most microbial counts were higher for fresh bolti fish and lowest for smoked mackerel. The use of salt and the smoking process might have affected the microbial counts. Irradiation caused a substantial reduction in all the microorganisms evaluated, and the reduction percentage was proportional to the irradiation dose. The lowest irradiation dose used (1.5 kGy) decreased the total aerobic bacterial counts of the fresh bolti fish by $7.5 \times 10^{3}$, while it decreased the total aerobic bacterial counts of smoked fish (herring and mackerel) by $4.4 \times 10^{3}$ and $2.0 \times 10^{3}$, respectively.

The higher reduction in the total aerobic bacterial count for fresh bolti fish might be due to the direct effect of the radiation as well as indirect effects resulting from water radiolysis, which is greater in fresh fish than in smoked fish. The highest irradiation dose used, i.e., $4.5 \mathrm{kGy}$, reduced the total aerobic bacterial counts by approximately $99.9 \%$ $(<100)$.

Considering that Staphylococcus aureus is the main food poisoning microorganism, irradiation, even at the lowest dose, destroyed almost all the cells of this dangerous microorganism $(<100)$. It could be concluded that irradiation doses used were sufficient to substantially reduce the counts of all the microbial species investigated and improve the hygienic quality of both fresh and smoked fish, rendering these products safe for human consumption. Many other investigators reported substantial reductions in the microbial counts on fish and fish products as a result of irradiation (Noomhorm et al., 2003; Duliu, Ferdes and Ferdes, 2004; Özkan et al., 2007; Demartini et al., 2019). It has been reported that irradiation doses of 1, 3, and $5 \mathrm{kGy}$ significantly reduced the total viable counts of microorganisms on rainbow trout fillets (Moini et al., 2009; Kakatkar et al., 2017).

Mendes et al. (2005) and Nickelson et al. (2001) found that the mesophilic bacterial counts of irradiated shrimp, crab, and fish were lower than those of nonirradiated samples during storage at $4{ }^{\circ} \mathrm{C}$. 
Table 1 Microbiological quality of fresh and smoked fish and before and after irradiation.

\begin{tabular}{|c|c|c|c|c|c|c|c|c|}
\hline \multirow{2}{*}{\multicolumn{2}{|c|}{$\begin{array}{l}\text { Microbiological quality } \\
\text { (Fresh bolti fish) }\end{array}$}} & \multicolumn{7}{|c|}{ Fresh bolti fish } \\
\hline & & \multicolumn{2}{|c|}{0 kGy } & \multicolumn{2}{|c|}{$1.5 \mathrm{kGy}$} & 3 kGy & \multicolumn{2}{|c|}{$4.5 \mathrm{kGy}$} \\
\hline \multicolumn{2}{|l|}{ Total aerobic bacteria } & \multicolumn{2}{|c|}{$8.2 \times 10^{5}$} & \multicolumn{2}{|c|}{$7.5 \times 10^{3}$} & $5.0 \times 10^{2}$ & \multicolumn{2}{|c|}{$1.1 \times 10^{2}$} \\
\hline \multicolumn{2}{|l|}{ Fecal streptococci } & \multicolumn{2}{|c|}{$3.0 \times 10^{3}$} & \multicolumn{2}{|c|}{$3.2 \times 10^{2}$} & $<100$ & \multicolumn{2}{|c|}{$<100$} \\
\hline \multicolumn{2}{|c|}{ Staphylococcus aureus } & \multicolumn{2}{|c|}{$3.3 \times 10^{2}$} & \multicolumn{2}{|c|}{$<100$} & $<100$ & \multicolumn{2}{|c|}{$<100$} \\
\hline \multicolumn{2}{|l|}{ Yeasts } & \multicolumn{2}{|c|}{$8.0 \times 10^{3}$} & \multicolumn{2}{|c|}{$6.1 \times 10^{2}$} & $1.0 \times 10^{2}$ & \multicolumn{2}{|c|}{$<10$} \\
\hline \multicolumn{2}{|l|}{ Molds } & \multicolumn{2}{|c|}{$0.7 \times 10^{2}$} & \multicolumn{2}{|c|}{$3.3 \times 10$} & $<10$ & \multicolumn{2}{|c|}{$<10$} \\
\hline \multirow{2}{*}{$\begin{array}{c}\text { Microbiological } \\
\text { quality } \\
\text { (Smoked herring } \\
\text { and Smoked } \\
\text { mackerel) } \\
\end{array}$} & \multicolumn{3}{|c|}{ Smoked herring } & & \multicolumn{4}{|c|}{ Smoked mackerel } \\
\hline & 0.0 kGy & $1.5 \mathrm{kGy}$ & 3 kGy & 4.5 kGy & 1.5 kGy & 0.0 kGy & 3 kGy & $4.5 \mathrm{kGy}$ \\
\hline $\begin{array}{l}\text { Total aerobic } \\
\text { bacteria }\end{array}$ & $6.2 \times 10^{4}$ & $4.4 \times 10^{3}$ & $2.0 \times 10^{2}$ & $7.1 \times 10$ & $2.0 \times 10^{3}$ & $3.0 \times 10^{4}$ & $4.1 \times 10^{2}$ & $6.0 \times 10$ \\
\hline Fecal streptococci & $1.9 \times 10^{2}$ & $1.1 \times 10$ & $<100$ & $<100$ & $1.1 \times 10$ & $7.0 \times 10^{2}$ & $<100$ & $<100$ \\
\hline $\begin{array}{l}\text { Staphylococcus } \\
\text { aureus }\end{array}$ & $7.2 \times 10^{2}$ & $<100$ & $<100$ & $<100$ & $<100$ & $2.2 \times 10^{2}$ & $<100$ & $<100$ \\
\hline Yeasts & $7.4 \times 10^{3}$ & $5.6 \times 10^{2}$ & $5.0 \times 10$ & $<10$ & $8.0 \times 10$ & $7.1 \times 10^{2}$ & $2.1 \times 10$ & $<10$ \\
\hline Molds & $1.5 \times 10^{3}$ & $7.3 \times 10$ & $<10$ & $<10$ & $<10$ & $<10$ & $<10$ & $<10$ \\
\hline
\end{tabular}

Table 2 Effect of irradiation on the peroxide values, acid values and thiobarbituric acid values (TBA) of fish products.

\begin{tabular}{|c|c|c|c|c|c|c|c|c|c|c|c|c|}
\hline \multirow[b]{2}{*}{ Parameters } & \multicolumn{4}{|c|}{ Fresh bolti fish } & \multicolumn{4}{|c|}{ Smoked herring } & \multicolumn{4}{|c|}{ Smoked mackerel } \\
\hline & $\begin{array}{c}0 \\
\text { kGy }\end{array}$ & $\begin{array}{c}1.5 \\
\mathrm{kGy}\end{array}$ & $\begin{array}{c}3 \\
\mathbf{k G y}\end{array}$ & $\begin{array}{c}4.5 \\
\mathrm{kGy}\end{array}$ & $\begin{array}{c}0.0 \\
\text { kGy }\end{array}$ & $\begin{array}{c}1.5 \\
\mathrm{kGy}\end{array}$ & 3 kGy & $\begin{array}{c}4.5 \\
\mathrm{kGy}\end{array}$ & $\begin{array}{c}1.5 \\
\mathrm{kGy}\end{array}$ & $\begin{array}{c}0.0 \\
\mathrm{kGy}\end{array}$ & 3 kGy & $\begin{array}{c}4.5 \\
\mathrm{kGy}\end{array}$ \\
\hline $\begin{array}{l}\text { Peroxide } \\
\text { value }\end{array}$ & $\begin{array}{c}5.7 \\
\pm 0.26 \\
\end{array}$ & $\begin{array}{c}7.9 \\
\pm 0.13 \\
\end{array}$ & $\begin{array}{r}9.8 \\
\pm 0.22 \\
\end{array}$ & $\begin{array}{c}14.3 \\
\pm 0.05 \\
\end{array}$ & $\begin{array}{r}7.5 \\
\pm 0.55 \\
\end{array}$ & $\begin{array}{r}9.2 \\
\pm 0.33 \\
\end{array}$ & $\begin{array}{c}11.1 \\
\pm 0.58 \\
\end{array}$ & $\begin{array}{c}15.9 \\
\pm 0.10 \\
\end{array}$ & $\begin{array}{c}8.3 \\
\pm 0.70 \\
\end{array}$ & $\begin{array}{c}9.9 \\
\pm 0.90 \\
\end{array}$ & $\begin{array}{c}12.5 \\
\pm 0.60\end{array}$ & $\begin{array}{c}13.7 \\
\pm 0.22 \\
\end{array}$ \\
\hline Acid value & $\begin{array}{c}0.8 \\
\pm 0.05\end{array}$ & $\begin{array}{c}0.96 \\
\pm 0.04 \\
\end{array}$ & $\begin{array}{c}1.2 \\
\pm 0.03 \\
\end{array}$ & $\begin{array}{c}1.87 \\
\pm 0.03 \\
\end{array}$ & $\begin{array}{c}1.15 \\
\pm 0.23 \\
\end{array}$ & $\begin{array}{c}1.52 \\
\pm 0.21\end{array}$ & $\begin{array}{c}2 \\
\pm 0.22 \\
\end{array}$ & $\begin{array}{c}2.55 \\
\pm 0.19\end{array}$ & $\begin{array}{c}1.37 \\
\pm 0.18\end{array}$ & $\begin{array}{c}1.7 \\
\pm 0.13 \\
\end{array}$ & $\begin{array}{c}2.11 \\
\pm 0.21 \\
\end{array}$ & $\begin{array}{c}2.7 \\
\pm 0.15\end{array}$ \\
\hline TBA & $\begin{array}{l}0.178 \\
\pm 0.04\end{array}$ & $\begin{array}{l}0.211 \\
\pm 0.07\end{array}$ & $\begin{array}{c}0.25 \\
\pm 0.08\end{array}$ & $\begin{array}{l}0.592 \\
\pm 0.04\end{array}$ & $\begin{array}{l}0.279 \\
\pm 0.46\end{array}$ & $\begin{array}{l}0.372 \\
\pm 0.23\end{array}$ & $\begin{array}{l}0.446 \\
\pm 0.33\end{array}$ & $\begin{array}{l}0.635 \\
\pm 0.23\end{array}$ & $\begin{array}{l}0.353 \\
\pm 0.04\end{array}$ & $\begin{array}{l}0.415 \\
\pm 0.04\end{array}$ & $\begin{array}{l}0.481 \\
\pm 0.03\end{array}$ & $\begin{array}{l}0.722 \\
\pm 0.06\end{array}$ \\
\hline
\end{tabular}

Note: Results are presented as mean $\pm S D(\mathrm{n}=3)$. Values are significantly differen $(p<0.05)$.

Table 3 Relative percentages of fatty acids in nonirradiated and irradiated fish products.

\begin{tabular}{|c|c|c|c|c|c|c|c|c|c|c|c|c|c|}
\hline \multirow[b]{2}{*}{ Fatty acids } & \multirow{2}{*}{$\begin{array}{c}\text { Carb } \\
\text { No. }\end{array}$} & \multicolumn{4}{|c|}{ Fresh Bolti Fish } & \multicolumn{4}{|c|}{ Smoked Herring } & \multicolumn{4}{|c|}{ Smoked Mackerel } \\
\hline & & $\begin{array}{c}0.0 \\
\text { kGy }\end{array}$ & $\begin{array}{c}1.5 \\
\text { kGy }\end{array}$ & $\begin{array}{c}3.0 \\
\text { kGy }\end{array}$ & $\begin{array}{c}4.5 \\
\text { kGy }\end{array}$ & $\begin{array}{c}0.0 \\
\text { kGy }\end{array}$ & $\begin{array}{c}1.5 \\
k G y\end{array}$ & $\begin{array}{c}3.0 \\
\text { kGy }\end{array}$ & $\begin{array}{c}4.5 \\
\text { kGy }\end{array}$ & $\begin{array}{c}0.0 \\
\text { kGy }\end{array}$ & $\begin{array}{c}1.5 \\
k G y\end{array}$ & $\begin{array}{c}3.0 \\
\text { kGy }\end{array}$ & $\begin{array}{c}4.5 \\
\text { kGy }\end{array}$ \\
\hline Lauric & 12.0 & 00.12 & 00.12 & 00.34 & 00.18 & 00.31 & 00.38 & 00.34 & 00.44 & 00.20 & 00.14 & 00.24 & 00.16 \\
\hline Myristic & 14.0 & 06.56 & 09.41 & 09.64 & 1.17 & 09.81 & 09.70 & 09.61 & 09.91 & 08.00 & 10.01 & 08.52 & 09.75 \\
\hline Pentadecanoic & 15.0 & 01.70 & 00.92 & 00.92 & 00.79 & 00.82 & 00.21 & 00.65 & 00.65 & 01.11 & 01.33 & 01.60 & 01.12 \\
\hline Palmitic & 16.0 & 28.65 & 28.22 & 27.70 & 27.79 & 00.21 & 00.15 & 00.87 & 01.50 & 00.24 & 00.21 & 00.20 & 00.24 \\
\hline Palmitoleic & 16.1 & 18.01 & 18.10 & 18.00 & 17.75 & 19.13 & 18.57 & 17.26 & 14.40 & 19.63 & 18.00 & 16.20 & 15.20 \\
\hline Heptadecanoic & 17.0 & 03.55 & 5.75 & 05.33 & 05.85 & 00.50 & 00.12 & 00.75 & 00.95 & 07.61 & 08.75 & 07.70 & 08.90 \\
\hline Heptadecanoic & 17.1 & 0.3 .68 & 3.00 & 04.12 & 04.28 & 00.83 & 00.12 & 00.19 & 01.34 & 02.35 & 01.26 & 01.31 & 00.72 \\
\hline Stearic & 18.0 & 0.6 .25 & 6.00 & 06.29 & 08.45 & 00.92 & 00.57 & 00.95 & 00.97 & 00.52 & 00.67 & 00.22 & 00.71 \\
\hline Oleic & 18.1 & 21.71 & 20.01 & 19.70 & 16.93 & 03.20 & 03.11 & 03.62 & 03.66 & 06.35 & 06.66 & 05.14 & 05.26 \\
\hline Linoleic & 18.2 & 05.16 & 4.51 & 03.89 & 02.32 & 18.43 & 18.70 & 18.03 & 19.00 & 20.51 & 17.29 & 17.29 & 24.00 \\
\hline Linol & 18.3 & 00.55 & 00.55 & 00.68 & 00.55 & 19.01 & 25.00 & 18.27 & 22.14 & 08.61 & 08.22 & 18.60 & 17.10 \\
\hline Arachidic & 20.0 & 0.1 .34 & 1.20 & 01.07 & 01.10 & 02.00 & 02.03 & 02.52 & 02.82 & 02.74 & 03.13 & 02.71 & 02.92 \\
\hline Gadoleic & 20.1 & 01.00 & 00.95 & 01.18 & 01.30 & 00.92 & 01.66 & 04.00 & 09.06 & 05.31 & 04.73 & 04.78 & 08.32 \\
\hline Eicosadienoic & 20.2 & 00.26 & 00.28 & 00.28 & 00.23 & 23.38 & 21.70 & 23.0 & 13.22 & 14.69 & 18.82 & 15.90 & 05.27 \\
\hline Eleostearic & 20.3 & 00.24 & 00.24 & 00.30 & 00.37 & 00.70 & - & - & - & 00.27 & 00.50 & 00.22 & 00.31 \\
\hline Arachidonic & 20.4 & 01.12 & 01.10 & 00.50 & 00.85 & 00.31 & - & - & - & 01.90 & 00.20 & - & - \\
\hline T. sat $*$ & & $\begin{array}{l}48.17 \\
\pm 1.23\end{array}$ & $\begin{array}{l}51.42 \\
\pm 2.62\end{array}$ & $\begin{array}{l}51.29 \\
\pm 2.05\end{array}$ & $\begin{array}{l}55.33 \\
\pm 2.75\end{array}$ & $\begin{array}{l}14.57 \\
\pm 2.05\end{array}$ & $\begin{array}{l}13.16 \\
\pm 1.65\end{array}$ & $\begin{array}{l}15.69 \\
\pm 0.65\end{array}$ & $\begin{array}{l}17.24 \\
\pm 0.58\end{array}$ & $\begin{array}{l}20.42 \\
\pm 1.23\end{array}$ & $\begin{array}{l}24.24 \\
\pm 2.62\end{array}$ & $\begin{array}{l}21.19 \\
\pm 0.63\end{array}$ & $\begin{array}{l}23.80 \\
\pm 0.45\end{array}$ \\
\hline T. Unsat ** & & $\begin{array}{l}51.73 \\
\pm 2.75\end{array}$ & $\begin{array}{l}48.78 \\
\pm 2.27\end{array}$ & $\begin{array}{l}48.95 \\
\pm 1.10\end{array}$ & $\begin{array}{l}44.58 \\
\pm 0.50\end{array}$ & $\begin{array}{l}85.41 \\
\pm 1.37\end{array}$ & $\begin{array}{l}88.86 \\
\pm 2.27\end{array}$ & $\begin{array}{l}84.37 \\
\pm 2.03\end{array}$ & $\begin{array}{l}82.82 \\
\pm 2.62\end{array}$ & $\begin{array}{l}79.62 \\
\pm 2.52\end{array}$ & $\begin{array}{l}75.68 \\
\pm 1.37\end{array}$ & $\begin{array}{l}78.90 \\
\pm 1.57\end{array}$ & $\begin{array}{l}62.21 \\
\pm 0.57\end{array}$ \\
\hline
\end{tabular}

Note: Results are presented as mean $\pm S D(\mathrm{n}=3)$. Values are significantly differen $(p<0.05)$. 
Table 4 Organoleptic evaluation of nonirradiated and irradiated fresh and smoked fish.

\begin{tabular}{|c|c|c|c|c|c|c|c|c|c|c|c|c|}
\hline \multirow[b]{2}{*}{ Parameters } & \multicolumn{4}{|c|}{ Fresh bolti fish } & \multicolumn{4}{|c|}{ Smoked herring } & \multicolumn{4}{|c|}{ Smoked mackerel } \\
\hline & $\begin{array}{c}0 \\
\mathbf{k G y}\end{array}$ & $\begin{array}{c}1.5 \\
\mathrm{kGy}\end{array}$ & $\begin{array}{c}\mathbf{3} \\
\mathbf{k G y}\end{array}$ & $\begin{array}{c}4.5 \\
\text { kGy }\end{array}$ & $\begin{array}{c}0.0 \\
\text { kGy }\end{array}$ & $\begin{array}{c}1.5 \\
\text { kGy }\end{array}$ & $\begin{array}{c}\mathbf{3} \\
\mathbf{k G y}\end{array}$ & $\begin{array}{c}4.5 \\
\mathrm{kGy}\end{array}$ & $\begin{array}{c}1.5 \\
\text { kGy }\end{array}$ & $\begin{array}{c}0.0 \\
\text { kGy }\end{array}$ & $\begin{array}{c}\mathbf{3} \\
\mathbf{k G y}\end{array}$ & $\begin{array}{c}4.5 \\
k G y\end{array}$ \\
\hline Appearance & $\begin{array}{c}8.5 \\
\pm 0.01\end{array}$ & $\begin{array}{c}8.4 \\
\pm 0.06\end{array}$ & $\begin{array}{c}8.5 \\
\pm 0.04\end{array}$ & $\begin{array}{c}8.3 \\
\pm 0.04\end{array}$ & $\begin{array}{c}8.6 \\
\pm 0.01\end{array}$ & $\begin{array}{c}8.6 \\
\pm 0.04\end{array}$ & $\begin{array}{c}8.7 \\
\pm 0.03\end{array}$ & $\begin{array}{c}8.2 \\
\pm 0.03\end{array}$ & $\begin{array}{c}8.9 \\
\pm 0.01\end{array}$ & $\begin{array}{c}8.7 \\
\pm 0.04\end{array}$ & $\begin{array}{c}8.7 \\
\pm 0.04\end{array}$ & $\begin{array}{c}8.5 \\
\pm 0.03\end{array}$ \\
\hline Odor & $\begin{array}{c}8.2 \\
\pm 0.04\end{array}$ & $\begin{array}{c}8 \\
\pm 0.07\end{array}$ & $\begin{array}{c}8 \\
\pm 0.07\end{array}$ & $\begin{array}{c}7.3 \\
\pm 0.11\end{array}$ & $\begin{array}{c}8.5 \\
\pm 0.02\end{array}$ & $\begin{array}{c}8.3 \\
\pm 0.04\end{array}$ & $\begin{array}{c}8 \\
\pm 0.07\end{array}$ & $\begin{array}{c}8 \\
\pm 0.09\end{array}$ & $\begin{array}{c}8.7 \\
\pm 0.01\end{array}$ & $\begin{array}{c}8.4 \\
\pm 0.02\end{array}$ & $\begin{array}{c}8.4 \\
\pm 0.02\end{array}$ & $\begin{array}{c}8 \\
\pm 0.04\end{array}$ \\
\hline Texture & $\begin{array}{c}8.7 \\
\pm 0.01\end{array}$ & $\begin{array}{c}8.6 \\
\pm 0.04\end{array}$ & $\begin{array}{c}8.3 \\
\pm 0.05\end{array}$ & $\begin{array}{c}8.3 \\
\pm 0.11\end{array}$ & $\begin{array}{c}8.3 \\
\pm 0.04\end{array}$ & $\begin{array}{c}8.5 \\
\pm 0.05\end{array}$ & $\begin{array}{c}8.2 \\
\pm 0.07\end{array}$ & $\begin{array}{c}8 \\
\pm 0.11\end{array}$ & $\begin{array}{c}8.3 \\
\pm 0.05\end{array}$ & $\begin{array}{c}8 \\
\pm 0.04\end{array}$ & $\begin{array}{c}8 \\
\pm 0.04\end{array}$ & $\begin{array}{c}7.8 \\
\pm 0.07\end{array}$ \\
\hline Taste & $\begin{array}{c}8.4 \\
\pm 0.03\end{array}$ & $\begin{array}{c}8.2 \\
\pm 0.07\end{array}$ & $\begin{array}{c}8 \\
\pm 0.03\end{array}$ & $\begin{array}{c}8 \\
\pm 0.12\end{array}$ & $\begin{array}{c}8.5 \\
\pm 0.02\end{array}$ & $\begin{array}{c}8.5 \\
\pm 0.04\end{array}$ & $\begin{array}{c}8 \\
\pm 0.05\end{array}$ & $\begin{array}{c}8 \\
\pm 0.05\end{array}$ & $\begin{array}{c}8.8 \\
\pm 0.01\end{array}$ & $\begin{array}{c}8.5 \\
\pm 0.04\end{array}$ & $\begin{array}{c}8.3 \\
\pm 0.05\end{array}$ & $\begin{array}{c}8.2 \\
\pm 0.05\end{array}$ \\
\hline
\end{tabular}

Results are presented as mean $\pm \mathrm{SD}(\mathrm{n}=3)$. Values are significantly differen $(p<0.05)$.

The effects of irradiation on the fish lipid quality attributes are presented in Table 2. Generally, irradiation increased the peroxide value, acid value, and thiobarbituric acid value (TBA) of both fresh and smoked fish, but the levels were still indicative of acceptable quality.

Irradiated fresh bolti fish and smoked fish (herring and mackerel) showed significantly higher peroxide values $\left(14.3,15.9\right.$ and 13.9 meqO${ }_{2} \cdot \mathrm{kg}^{-1}$ at $\left.4.5 \mathrm{kGy}\right)$ than the control samples $\left(5.7,7.5\right.$ and $\left.8.3 \mathrm{meqO}_{2} . \mathrm{kg}^{-1}\right)$, respectively, and the peroxide values were positively correlated with the dose used. The results of this study are in agreement with the findings of other studies that have reported an increase in oxidation activity and lipid peroxidation as a result of radiation treatment of fish and fish products (Ahn et al., 2000; Byun et al., 2008; Rostamzad et al., 2010). In contrast, Javanmard et al. (2006) reported no significant $(p>0.05)$ differences in the peroxide value between irradiated and control chicken meat after irradiation.

TBA values revealed that irradiation caused an increase in lipid oxidation in fish samples. The rate of the increase was correlated with the irradiation dose, and the highest increase was observed in the thiobarbituric acid values $(0.592,0.635$, and $0.722 \mathrm{mg} \mathrm{MDA} . \mathrm{kg}^{-1}$ at $4.5 \mathrm{kGy}$ ), indicating that the peroxides and hydroperoxides degraded into lowmolecular-weight compounds. Similarly, some researchers have shown increases in TBA values during irradiation of various fish and fish products (Byun et al., 2008; Turgis et al., 2008). In contrast, Chun et al. (2010) reported no significant differences in the TBARS values with both increasing irradiation doses and increasing storage periods in chicken breasts.

Comparing fresh bolti, smoked herring and smoked mackerel revealed that the greatest increase in lipid quality attributes occurred in fresh bolti fish, and the smallest increase occurred in smoked mackerel fish.

The fatty acid compositions of fresh bolti fish and smoked fish (herring and mackerel) are shown in Table 3. The compositions of the irradiated and nonirradiated samples were qualitatively similar since no new fatty acids or other artifacts were generated by irradiation. Among all the fatty acids, palmitoleic acid (C16:1) (17.75, 14.40, and 15.20\% at $4.5 \mathrm{kGy}$ and $18.01,19.13$, and $19.63 \%$ in the control, respectively) was the most abundant fatty acid in all the irradiated and nonirradiated samples. The least abundant fatty acid was lauric acid (C12:0) $(0.18,0.44$, and $00.16 \%$ at $4.5 \mathrm{kGy}$ and $0.12,0.31$, and $0.20 \%$ in the control, respectively) in all the irradiated and nonirradiated samples. The relative percentage of total polyunsaturated fatty acids for all fats in the fish samples decreased slightly with increasing radiation dose $(44.58,82.82,62.21 \%$ at $4.5 \mathrm{kGy}$ and $51.73,85.41,79.62 \%$ for the control), suggesting the potential for the oxidation of unsaturated compounds by irradiation.

Fresh bolti fish, which are considered lean fish, have a lower percentage of unsaturated fatty acids than the other tested fish, suggesting that the higher susceptibility of the fat in bolti fish to oxidation by irradiation may be due to the high content of monounsaturated fatty acids that are easily oxidized.

There were no significant differences $(p>0.05)$ in the levels of all fatty acids, saturated fatty acids, or unsaturated fatty acids between the control and irradiated fish samples at $1.5,3.0$, and $4.5 \mathrm{kGy}$. Therefore, the irradiation process had no significant effect $(p>0.05)$ on the fatty acid composition.

Javan and Motallebi (2015) reported an increase in fatty acid oxidation with increasing dose of gamma irradiation in their study of the effects of different doses of gamma radiation $(0,0.75,1.5,2.25,3,3.75$, and $4.5 \mathrm{kGy})$ on the fatty acid composition of rainbow trout fillets.

Oraei et al. (2011) also reported that different irradiation processes and doses of radiation $(1,3$, and $5 \mathrm{kGy})$ had no significant effects $(p>0.05)$ on the fatty acid composition of rainbow trout fillets.

Al-Kahtani et al. (1996) reported the influence of irradiation on the chemical components of tilapia and Spanish mackerel, and radiation doses of $1.5-10 \mathrm{kGy}$ caused a decrease in some fatty acids. Erkan and Özden (2007) reported that the total fatty acid contents in the muscle of nonirradiated sea bream were lower than in sea bream irradiated with $2.5 \mathrm{kGy}$ and higher than in sea bream irradiated with $5 \mathrm{kGy}$.

Mbarki et al. (2009) reported that low-dose irradiation had no adverse effect on the nutritionally important polyunsaturated fatty acids in Mediterranean horse mackerel.

Özden and Erkan (2010) reported that the total saturated and total monounsaturated fatty acids in irradiated sea bass increased at 2.5 and $5 \mathrm{kGy}$, and the total polyunsaturated fatty acid contents in irradiated samples were higher than that in nonirradiated samples.

The organoleptic scores (for appearance, odor, texture, and taste) for fresh fish and smoked fish are shown in Table 4). Smoked mackerel earned the highest scores, while fresh bolti fish earned the lowest scores. Irradiation reduced the organoleptic scores of all the tested fish samples, but the reduction was not significant. The reduction was proportional to the radiation dose, and the largest reduction 
was observed for fresh bolti fish, especially in odor and taste. The average appearance scores for the nonirradiated samples were 8.5, 8.6, and 8.9. For the irradiated samples, the scores were 8.3, 8.2, and 8.5 at $4.5 \mathrm{kGy}$. Both the irradiated and nonirradiated samples were in acceptable conditions. Considering the organoleptic evaluation, the optimum radiation dose for fresh bolti fish is less than or equal to $3.0 \mathrm{kGy}$. Smoked herring and smoked mackerel can be irradiated up to $4.5 \mathrm{kGy}$ without adversely affecting their chemical and organoleptic properties.

Our results agreed with the results of Prakash et al. (2014) and Badr (2012), who reported that irradiated and nonirradiated dry fish were in acceptable condition. WHO (2000) and Ahmed et al. (2009) showed that radiation doses up to $5 \mathrm{kGy}$ had a significant effect on the visual qualities, decay rate, color, and texture of minimally processed foods. Alam, Ahmed and Shahin (2009) showed good correlations between bacterial populations and the overall acceptability scores with the shelf life of hilsa.

\section{CONCLUSION}

The irradiation of food enhances the safety and the hygienic qualities of fresh and smoked fish products because of its high efficacy for inactivating pathogenic and spoilage microorganisms without deteriorating the quality of the product.

According to all the obtained data, gamma irradiation, especially $4.5 \mathrm{kGy}$, can be applied for microbial control and improving the safety of smoked fish, and increasing its shelf life without adverse effects on its organoleptic properties. Also, the current study showed that irradiation of $4.5 \mathrm{kGy}$ greatly reduced the organoleptic quality scores of fresh bolti fish, indicating that the optimum radiation dose of this fish is $3.0 \mathrm{kGy}$.

\section{REFERENCES}

Ahmed, M. K., Hasan, M., Alam, M. J., Ahsan, N., Islam, M. M., Akter, M. S. 2009. Effect of gamma radiation in combination with low temperature refrigeration on the chemical, microbiological and organoleptic changes in pampus chinensis (Euphrasen, 1788). World J. Zool., vol. 4, no. 1, p. 913.

Ahn, H. J., Lee, C. H., Lee, K. H., Kim, J. H., Cha, B. S., Byun, M. W. 2000. Processing of low salted and fermented shrimp using gamma irradiation before optimum fermentation. Korean Journal of Food Science and Technology, vol. 32, no. 5, p.1107-1113.

Alam, M., Ahmed, K., Shahin, M. 2009. Effects of gamma radiation and-20 $\mathrm{C}$ temperatures on the shelf life of Hilsa, Tenualosa ilisha (ham.-Buch. 1822). Bangladesh J. Fish Res., vol. 13 , no. 2 , p. 153-60.

Al-Kahtani, H. A., Abu-Tarboush, H. M., Bajaber, A. S., Atia, M., Abou-Arab, A. A., El-Mojaddidi, M. A. 1996. Chemical changes after irradiation and post-irradiation storage in Tilapia and Spanish Mackerel. J. Food Sci., vol. 61, no. 4, p. 729-33. https://doi.org/10.1111/j.1365-2621.1996.tb12191.x

AOAC. 1990. Official methods of analysis of the association of official analytical chemists. Association of Official Analytical Chemists. $15^{\text {th }}$ ed. Arlington, Virginia : AOAC, p. 977.

APHA. 1998. Standard methods for the examination of water and wastewater. $20^{\text {th }}$ ed. Washington : APHA, 2671 p. ISBN 0-87553-235-7.
Badr, H. M. 2012. Control of the potential health hazards of smoked fish by gamma irradiation. Int. J. Food Microbiol., vol. 154, no. 3, p. 177-186. https://doi.org/10.1016/j.ijfoodmicro.2011.12.037

Brennan, J. G. 2005. Food processing: handbook. Weinheim, Germany : Wiley-VCH., p. 105-110. ISBN 9783527607570. https://doi.org/10.1002/3527607579

Byun, H. G., Taekil, E., Jung, W-K., Kim, S-K. 2008. Characterization of fish oil extracted from fish processing byproducts. Preventive Nutrition and Food Science, vol. 13, no. 1, p. 7-11. https://doi.org/10.3746/jfn.2008.13.1.007

Chouliara, I., Savvaidis, I. N., Panagiotakis, N. , Kontominas, M. G. 2004. Preservation of salted, vacuum-packaged, refrigerated sea bream (Sparus aurata) fillets by irradiation: Microbiological, chemical and sensory attributes. Food Microbiol., vol. 21, no. 3, p. 351-359. https://doi.org/10.1016/S0740-0020(03)00065-0

Chun, H. H., Kim, J. Y., Lee, B. D., Yu, D. J., Song, K. B. 2010. Effect of UV-C irradiation on the inactivation of inoculated pathogens and quality of chicken breasts during storage. Food Control, vol. 21, no. 3, p. 276-280. https://doi.org/10.1016/j.foodcont.2009.06.006

Demartini, E., Gaviglio, A., La Sala, P., Fiore, M. 2019. Impact of information and Food Technology Neophobia in consumers' acceptance of shelf-life extension in packaged fresh fish fillets. J. Sustainable Production and Consumption, vol. 17, p.116-125. https://doi.org/10.1016/j.spc.2018.09.006

Du, M., Ahn, D. U., Nam, K. C., Sell, J. L. 2000. Influence of dietary conjugated linoleic acid on volatile profiles, color and lipid oxidation of irradiated raw chicken meat. Meat Sci., vol. 56, no. 4, p. 387-395. https://doi.org/10.1016/S03091740(00)00067-X

Duliu, O. G., Ferdes, M., Ferdes, O. S. 2004. EPR study of some irradiated food enzymes. J. Radioanal. Nucl. Chem., vol. 260 ,

$$
\mathrm{p} \text {. }
$$

https://doi.org/10.1023/B:JRNC.0000027095.19005.e7

Erkan, N., Özden, Ö. 2007. The changes of fatty acid and amino acid compositions in sea bream (Sparus aurata) during irradiation process. Radiat. Phys. Chem., vol. 76, no. 10, p. 1636-1641.

https://doi.org/10.1016/j.radphyschem.2007.01.005

Fallah, A. A., Tajik, H., Rohani, S. M. R., Rahnama, M. 2008. Microbial and sensory characteristics of camel meat during refrigerated storage as affected by gamma irradiation. Pak. J. Biol. Sci., vol. 11, no. 6, p. 894-899. https://doi.org/10.3923/pjbs.2008.894.899

Farkas, J. 2006. Irradiation for better foods. Trends in Food Science \& Technology, vol. 17, no. 4, p. 148-152. https://doi.org/10.1016/j.tifs.2005.12.003

Javan, S., Motallebi, A. A. 2015. Changes of fatty acid profile during gamma irradiation of rainbow trout (Oncorhynchus mykiss) fillets. Int. J. Meat. Sci., vol. 5, no. 1, p. 1-7. https://doi.org/10.3923/ijmeat.2015.1.7

Javanmard, M., Rokni, N., Bokaie, S., Shahhosseini, G. 2006. Effects of gamma irradiation and frozen storage on microbial, chemical and sensory quality of chicken meat in Iran. Food Control, vol. 17, no. 6, p. 469-473. https://doi.org/10.1016/j.foodcont.2005.02.008

Kakatkar, A. S., Gautam, R. K., Shashidhar, R. 2017. Combination of glazing, nisin treatment and radiation processing for shelf-life extension of seer fish (Scomberomorous guttatus) steaks. Radiation Physics and Chemistry, vol. 130, p. 303-305. https://doi.org/10.1016/j.radphyschem.2016.09.017

Lacroix, M., Ouattara, B. 2000. Combined industrial processes with irradiation to assure innocuity and preservation 
of food products - a review. Food Res. Int., vol. 33, no. 9, p. 719-24. https://doi.org/10.1016/S0963-9969(00)00085-5

Lynch, S. M., Frei, B. 1993. Mechanism of copper-and irondependent oxidative modification of human low density lipoprotein. J. Lipid Research, vol. 34, no. 10, p. 1745-1753. https://doi.org/10.1016/S0022-2275(20)35737-0

Maturin, L., Peeler, J. T. 2001 BAM Chapter 3: Aerobic Plate Count. US : FDA/CFSAN, 11 p.

Mbarki, R., Sadok, S., Barkallah, I. 2009. Quality changes of the Mediterranean horse mackerel (Trachurus mediterraneus) during chilled storage: The effect of low-dose gamma irradiation. Radiat. Phys. Chem., vol. 78, no. 4, p. 288-292. https://doi.org/10.1016/j.radphyschem.2008.12.004

Mendes, R., Silva, H. A., Nunes, M. L., Empis, J. M. A. 2005. Effect of low-dose irradiation and refrigeration on the microflora, sensory characteristics and biogenic amines of Atlantic horse mackerel (Trachurus trachurus). Eur. Food Res. Technol., vol. 221, p. 329-335. https://doi.org/10.1007/s00217005-1172-x

Moini, S., Tahergorabi, R., Hosseini, S. V., Rabbani, M., Tahergorabi, Z., Feas, X., Aflaki, F. 2009. Effect of gamma radiation on the quality and shelf life of refrigerated rainbow trout (Oncorhynchus mykiss) fillets. J. Food Prot., vol. 72, no. 7, p. 1419-1426. https://doi.org/10.4315/0362-028x-72.7.1419 Nickelson, R. I., McCarthy, S., Finne, G. 2001. Fish, crustaceans, and precooked seafoods. In Downes, F. P., Ito, K. Compendium of methods for the microbiological examination of foods. Washington, USA : American Public Health Association, p 497-505. ISBN 9780875532738. https://doi.org/10.2105/9780875531755ch48

Noomhorm, A., Vongsawasdi, P., Inprasit, C., Yamprayoon, J., Sirisoontaralak, P., Ingles, M. E. A., Adulpichit, A. 2003. Radiation processing for safe, shelf-stable and ready-to-eat food. Austria : IAEA, 264 p. ISBN 92-0-100703-5.

Oraei, M., Motalebi, A., Hoseini, E., Javan, S., Hemmasi, A. 2011. Effect of gamma irradiation on fatty acid composition of rainbow trout (Oncorhynchus mykiss) fillets. Iran J. Fish Sci., vol. 10 , no. 2 , p. $276-285$.

Özden, Ö., Erkan, N. 2010. Impacts of gamma radiation on nutritional components of minimal processed cultured sea bass (Dicentrarchus labrax). Iran J. Fish Sci., vol. 9, no. 2, p. 265278.

Özkan, Ö., Müge, İ., Nuray, E. 2007. Effect of different dose gamma radiation and refrigeration on the chemical and sensory properties and microbiological status of aqua cultured sea bass (Dicentrarchus labrax). Radiat. Phys. Chem., vol. 76, no. 7, p. 1169-1178.

https://doi.org/10.1016/j.radphyschem.2006.11.010
Prakash, S., Jeyasanta, K. I., Edward, J. P., Patterson, J. 2014. Effect of gamma irradiation on the microbial quality of dried fishes. Asia J. Appl. Microbiol., vol. 1, p. 26-48.

Rostamzad, H., Shabanpour, B., Kashaninejad, M., Shabani, A. 2010. Inhibitory impacts of natural antioxidants (ascorbic and citric acid) and vacuum packaging on lipid oxidation in frozen Persian sturgeon fillets. Iran J. Fish. Sci., vol. 9, p. 27992.

Sedeh, F. M., Arbabi, K., Fatolahi, H., Abhari, M. 2007. Using gamma irradiation and low temperature on microbial decontamination of red meat in Iran. Indian J. Microbiol., vol. 47, p. 72-6. https://doi.org/10.1007/s12088-007-0013-y

Tallent, S., Hait, J., Bennett, R. W., Lancette, G. A. 2001. Bam Chapter12: Staphylococcus aureus. US : FDA/CFSAN, 6 p.

Tournas, V., Stack, M. E., Mislivec, P. B., Koch, H. A., Bandler, R. 2001. BAM Chapter 18: Yeasts, Molds and Mycotoxins. US : FDA/CFSAN, $12 \mathrm{p}$.

Turgis, M., Han, J., Borsa, J., Lacroix, M. 2008. Combined effect of natural essential oils, modified atmosphere packaging, and gamma radiation on the microbial growth on ground beef. J. Food Prot., vol. 71, p. 1237-1243. https://doi.org/10.4315/0362-028x-71.6.1237

WHO. 2000. The WHO golden rules for safe food preparation. Geneva, Switzerland: WHO, 1 p.

\section{Acknowledgments:}

The author is grateful to Princess Nourah Bint Abdulrahman University for the excellent encouragement and support in the execution of this work. The author is also grateful to King Abdul Aziz City for Science and Technology (KACST) for their help in performing the irradiation.

\section{Conflict of Interest:}

The authors declare no conflict of interest.

\section{Contact Address:}

*Amal Nasser Al-Kuraieef, Princess Nourah Bint Abdulrahman University, Nutrition and Food Sciences Department, Riyadh, Saudi Arabia, PO Box 84428, Tel.: +966505218553

E-mail: analkuraieef@pnu.edu.sa

ORCID: https://orcid.org/0000-0003-2640-4436 